\title{
The use of functional stylistics in analyzing a portion of "The Wedding Dance"
}

\author{
El uso de la estilística funcional en el análisis de una parte de "El baile de la boda" \\ O uso de estilística funcional na análise de uma porção de "A Dança do Casamento"
}

Rhonex P. Paras

parasrhonex@gmail.com

Davao del Sur School of Fisheries, Bagumbayan, Malalag, Davao del Sur https://orcid.org/0000-0001-5075-0828

\begin{abstract}
This paper aims to analyze the transitivity patterns used in one of the most prominent short stories in Philippine Contemporary Literature "The Wedding Dance" which was written by a renowned writer Amador T. Daguio.

This study is based on Halliday's framework of transitivity analysis to delve on the meaning of the story in the literary discourse.

This paper used the simple random sampling among the short stories in the Grade 7 English Learning Material from the Department of Education. In addition, the story is divided into three parts according to the number of sentences. Subsequently, part of the story has been identified and selected as basis for the analysis through random selection process.

Furthermore, the paper used all 15 sentences from the first portion of the short story to be analyzed and interpreted using the functional stylistics. Analyzing and interpreting a portion of the short story in the context of functional stylistics played an integral part for it provided a portion of in depth understanding and interpretation of how each process type works and functions. It is also evident that the distribution of process type varies in different yet meaningful ways.
\end{abstract}

Thus, by examining the transitivity process in the text is indeed indispensable for it explained how the field of the situation is being constructed, and have clear idea how transitivity patterns reflected the nature of the text.

Keywords: Transitivity Analysis, Process Types, Functional Analysis

\section{RESUMEN}

Este artículo tiene como objetivo analizar los patrones de transitividad utilizados en uno de los cuentos más destacados de la literatura contemporánea filipina, "The Wedding Dance", escrito por el reconocido escritor Amador T. Daguio.

Este estudio se basa en el marco de análisis de la transitividad de Halliday para ahondar en el significado de la historia en el discurso literario.

Este documento utilizó el muestreo aleatorio simple entre los cuentos del Material de aprendizaje de inglés de séptimo grado del Departamento de Educación. Además, la historia se divide en tres partes según el número de frases. Posteriormente, parte de la historia ha sido identificada y seleccionada como base para el análisis mediante un proceso de selección aleatoria.

Además, el artículo utilizó las 15 oraciones de la primera parte del cuento para ser analizadas e interpretadas utilizando la estilística funcional. Analizar e interpretar una parte del cuento en el contexto de la estilística funcional jugó un papel integral, ya que proporcionó una parte de comprensión e interpretación en profundidad de cómo funciona y funciona cada tipo de proceso. También es evidente que la distribución del tipo de proceso varía de formas diferentes pero significativas. 
Así, examinar el proceso de transitividad en el texto es ciertamente indispensable para que se explique cómo se está construyendo el campo de la situación, y tener una idea clara de cómo los patrones de transitividad reflejan la naturaleza del texto.

Palabras clave: Análisis de transitividad, tipos de procesos, Análisis funcional

\section{RESUMO}

Este artigo tem como objetivo analisar os padrões de transitividade utilizados em um dos contos mais proeminentes da literatura contemporânea filipina, "The Wedding Dance", de autoria do renomado escritor Amador T. Daguio.

Este estudo é baseado na estrutura de análise de transitividade de Halliday para aprofundar o significado da história no discurso literário.

Este artigo usou a amostragem aleatória simples entre os contos no Material de Aprendizagem de Inglês da $7^{\mathrm{a}}$ série do Departamento de Educação. Além disso, a história é dividida em três partes de acordo com o número de frases. Posteriormente, parte da história foi identificada e selecionada como base para a análise por meio do processo de seleção aleatória.

Além disso, o artigo usou todas as 15 frases da primeira parte do conto para serem analisadas e interpretadas usando a estilística funcional. Analisar e interpretar uma parte da história curta no contexto da estilística funcional foi parte integrante, pois forneceu uma parte de compreensão e interpretação aprofundadas de como cada tipo de processo funciona e funciona. Também é evidente que a distribuição do tipo de processo varia de maneiras diferentes, mas significativas.

Assim, examinar o processo de transitividade no texto é de fato indispensável, pois explica como o campo da situação está sendo construído, e tem ideia clara de como os padrões de transitividade refletem a natureza do texto.

Palavras-chave: Análise de transitividade, tipos de processos, Análise funcional

\section{INTRODUCTION}

Literature is the cornerstone of life. It encompasses distinct topics from human tragedies to tales of the ever-popular search for love. While it is physically written in words, these words come alive in the imagination of the mind, and its ability to understand and analyze the complexity or simplicity of the text.

Understanding the depth and craftsmanship of any literary pieces poses challenges. It requires the analysis of the language to provide an objective interpretation and meaning of the literary text. It demands awareness on how the language works, its functions and components. From this point, understanding stylistics is quintessential Pilar (2012).

The function of stylistics is to help the reader stimulate, the significance of a literary text by analyzing the interrelations between its linguistic items. This approach is essentially selective. It aims to identify the stylistically significant, or stylistically distinctive, features in a literary text and to study their function in the text ass a whole. Stylistics occupies the middle ground between linguistics and literary criticism and its function is to mediate between the two. In this role, its concerns necessarily overlap with those of the two disciplines. It is for the reason that stylistic analysis shades indiscernibly into literary appreciation. Therefore, literary analysis seeks the assistance of stylistic analysis which is of a complementary nature to it. Stylistic analysis usually seeks to identify what stimulates and guides the reader or listener in the literary work (How the study of stylistics can help improve one's English Language. (2016, Aug 17). 
Moreover, in the context of transitivity analysis, transitivity is termed by Halliday (1967, p. 37) as "transitivity system", is concerned with the type of process expressed in the clause, with the participants in this process (animate and inanimate) and with various attributes and circumstances of the process and the participants. Being pertinent to the ideational function, i.e., the semantic content of language, transitivity is geared towards the grammar of experience that reflects the representations of the speaker's world (Halliday \& Matthiessen, 2004). Transitivity, as an integral sub-network of the system network, is now playing a part and attention in functional stylistic analysis.

Furthermore, as to the result of this study, the researcher will be able identify the types of processes evident in the story "The Mats" and how the transitivity analysis helps in interpreting the character construction in the story.

\section{Statement of the Problem}

This paper seeks to identify the types of transitivity processes found in "The Wedding Dance" from the context of functional stylistic analysis.

Specifically, this aims to answer the following questions.

1. What are the types of processes evident in the story "The Mats"?

2. How transitivity analysis helps in interpreting the character construction in the story?

\section{METHODOLOGY}

The study focused on close analysis on the first portion of the story 'The Wedding Dance". In identifying and selecting a specific story as basis for analysis, the researcher used simple random sampling among the short stories in the Grade 7 English Learning Material in Davao del Sur School of Fisheries, Malalag Davao del Sur.

Hayes (2019) defined simple random sample as a subset of a statistical population in which each member of the subset has an equal probability of being chosen. A simple random sample is meant to be an unbiased representation of a group.

The researcher then divided the story into three parts according to the number of sentences. Subsequently, the researcher identified and selected the part of the short story to be analyzed through random selection process.

Furthermore, the researcher used all 15 sentences from the first portion of the short story to be analyzed and interpreted using the functional stylistics.

Then, as to the analysis and interpretation of the first portion of the short story, analysis of process types in transitivity system as an important branch of Halliday's Systemic Functional Grammar was used as the system which concerns with how entities and actions in a situation are coded in the language.

As to data analysis and interpretation, simple statistics is used such as frequency and percentage.

The design is presented in the following diagram:

Process Type

$f$

$\%$ 


$\begin{array}{ll}1 & \text { Material Process } \\ 2 & \text { Mental Process } \\ 3 & \text { Relational Process } \\ 4 & \text { Behavioral Process } \\ 5 & \text { Verbal Process } \\ 6 & \text { Existential Process }\end{array}$

Where:

Material Process
Mental Process
Relational Process

Behavioral Process

Verbal Process

Existential Process refers to physical experience of human beings. refers to verbs indicating perception, cognition, affection, and desire refers to being and relation among entities through identification, attribution, and possession

refers to physiological and psychological behaviour, like breathing, dreaming, snoring, smiling, hiccupping, looking, watching, listening, and pondering refers to activities related to information which includes that of saying, commanding, asking, and offering.

refers to something exists or happens.

\section{RESULTS AND DISCUSSION}

In this section, transitivity processes and patterns in the context of the short story "The Wedding Dance is presented.

\subsection{Different Process Types}

Table 1 showed the sample clauses that signify the type of processes employed in the first portion of the short story "The Wedding Dance". It is revealed that out of 32 clauses (attached in Appendix A), five processes are present in the first portion of the short story.

Material process present is evident in the first clause specifically in 1a (Awiyao reached for the upper horizontal $\log$ ). Mental process is also observable in the fourth clause particularly in $4 \mathrm{a}$ (After some moments during which he seemed to wait).

On the other hand, Behavioral process is also noticeable in the second clause specifically in $2 \mathrm{~b}$ (He lifted himself with one bound) and for the Verbal process it can be observed in the fourth clause mainly in $4 \mathrm{~b}$ (He talked to the listening darkness). Relational process is also manifested in the first clause particularly in $1 b$ (Served as the edge of the head high threshold)

Finally, Existential process is also shown in the tenth clause specifically in 10a (There was a sudden rush of fire in her).

Table 1: Examples of different processes types from the first part of "The Wedding Dance"

\begin{tabular}{lcc}
\hline & Process Type & Example \\
1 & Material & Awiyao reached for the upper horizontal log (1a) \\
2 & Mental & After some moments during which he seemed to \\
& Wait (4a) \\
3 & Behavioral & He lifted himself with one bound (2b) \\
4 & Verbal & He talked to the listening darkness (4b) \\
5 & Relational & Served as the edge of the head high threshold (1b)
\end{tabular}




\subsection{Total Counts of Process}

Table 2 revealed the number of processes used in the first portion of the short story entitled "The Wedding Dance".

The table showed that the two predominant process types among all categories are the material and behavioral processes which both obtained a highest percentage of $27 \%$. Further, both of the process types were equally distributed and used.

The behavioral process is apparent in the clauses in $2 b, 3 b, 3 c, 7 a, 9 b, 11 c, 14 b, 15 a$ and $15 c$.

$\begin{array}{lll}2 \mathrm{~b} & - & \text { He lifted himself with one bound } \\ 3 \mathrm{~b} & - & \text { Stepped inside } \\ 3 \mathrm{c} & - & \text { Then pushed the cover back in place } \\ 7 \mathrm{a} & - & \text { But neither of us can help it } \\ 9 \mathrm{~b} & - & \text { When the sliding door opened } \\ 11 \mathrm{c} & - & \text { Continued to sit unmoving in the darkness } \\ 14 \mathrm{~b} & - & \text { Blew into the stove } \\ 15 \mathrm{a} & - & \text { When the coals began to glow } \\ 15 \mathrm{c} & - & \text { Then full round logs as his arms }\end{array}$

The behavioral process is the process of typically human physiological and psychological behavior. Normally, a behavioral process has only one participant: the human Behaver. Being partly like the material process and partly like the mental process, the behavioral process is the least distinct of all the six process types, especially in the language of science.

According to Matthiessen (2010) behavioral processes are processes of physiological and psychological behavior, and they are on the borderline between material and mental processes. Behavioral processes "represent outer manifestations of inner workings, the acting out of processes of consciousness and physiological states" (Halliday 1994:107). Behavioral processes are the least salient of Halliday's six process types, and the boundaries of behavioral processes are indefinite. The participant who is behaving is called Behaver. Like the Senser, Behaver is usually a conscious being, but the process is more like one of doing, as in material processes.

For the material process, it was mainly used particularly in the clauses in 1a, 2a, 3a, 9a, 9c 11a, 13a, 14a and 15b.

$\begin{array}{lll}1 \mathrm{a} & - & \text { Awiyao reached for the upper horizontal log } \\ 2 \mathrm{a} & - & \text { Clinging to the log } \\ 3 \mathrm{a} & - & \text { He slid back the cover } \\ 9 \mathrm{a} & - & \text { The woman who had moved with a start } \\ 9 \mathrm{c} & - & \text { Had been hearing the gangsas } \\ 11 \mathrm{a} & - & \text { She gave no sign } \\ 13 \mathrm{a} & - & \text { He crawled on all fours to the middle of the room } \\ 14 \mathrm{a} & - & \text { With bare fingers he stirred the covered smoldering embers } \\ 15 \mathrm{~b} & - & \text { Awiyao put pieces of pine on them }\end{array}$

In Halliday's transitivity system, the material process, a process of doing, usually describes concrete and tangible actions. The process expresses the notion that a participant, the Actor, "does" something - which may be done "to" some other participant, the Goal. 
Material processes are processes of doing in the physical world. Material processes have two inherent participants involved in them. The first of these is the Actor, which is an obligatory element and expresses the doer of the process. The second is the Goal, which is an optional element and expresses the person or entity whether animate or inanimate affected by the process. In addition to these two inherent participant roles, there is an extra element called Circumstance, which provides additional information on the "when, where, how, and why" of the process. The Circumstantial meaning is realized, not in nominal phrases, 1 but as either adverbial phrases or prepositional phrases, and so is subsidiary in status to the process. Circumstance expresses supplementary information, such as place, time, extent, matter, manner, duration, condition, and means.

Material processes are processes of material doing - they express the notion that some entity physically does something - which may be done to some other entitiy (Gerot \& Wignell, 1995). That is why Material processes also answer the question What did X do? or What happened? Its potential participants can be an Actor, a Goal, a Range (thing unaffected by the process) and a Beneficiary (the one to whom or for whom the process is said to take place) (Butt et al, 2000).

The mental process has also obtained $25 \%$ and it is observed more specifically in the clauses in $4 a, 9 d, 11 b, 12 a, 12 b, 12 c, 13 b$ and $16 a$.

$\begin{array}{lll}4 \mathrm{a} & - & \text { After some moments during which he seemed to wait } \\ 9 \mathrm{~d} & - & \text { For she did not know how long } \\ 11 \mathrm{~b} & - & \text { She heard Awiyao } \\ 12 \mathrm{a} & - & \text { Awiyao knew } \\ 12 \mathrm{~b} & - & \text { She heard him } \\ 12 \mathrm{c} & - & \text { His heart pitied her } \\ 13 \mathrm{~b} & - & \text { He knew exactly where the stove was } \\ 16 \mathrm{a} & - & \text { The room brightened }\end{array}$

The mental process accounts for the process of sensing and involves not material actions but phenomena best described as states of mind or psychological events. A mental process should have two participants, the Senser (endowed with consciousness) and the Phenomenon (realized as a thing or as a fact).

Mental processes are processes of "sensing". This process of sensing may be construed as flowing from a person's consciousness or as impinging on it (Halliday, 1985: 107). Mental processes differ from Material ones and therefore they require a different functional interpretation. While Material processes are concerned with our experience of the material world, Mental processes on the other hand are concerned with our experience of the world of our own consciousness. Mental processes may be of four sub-types: perception, which refers to processes of feeling, seeing, and so forth; cognition, which refers to processes of thinking, knowing, etc,; emotion/affection, refers to processes of liking, hating, etc.; and desideration, which refers to processes of wanting, and so forth. In a Mental process there is always a conscious participant, the Senser and also called Experiencer, who perceives, knows and so forth, and a second participant, the Phenomenon, that which is perceived, known, or liked (Downing, 2006:139).

Moreover, verbal process was used once in the fourth clause particularly in $4 \mathrm{~b}$ with $3 \%$.

\section{He talked to the listening darkness}

The verbal process is the process of saying. It characteristically involves three participants: the Sayer, the Receiver and the Verbiage. The Sayer, the participant responsible for the verbal process, is typically but not necessarily conscious. The Receiver is the participant to whom the saying is directed. The Verbiage is characterized by nouns expressing verbal behavior, such as question, story and report. 
A verbal process is the process of saying, and it exists on the borderline between mental and relational processes. Just like saying and meaning, the verbal process expresses the relationship between ideas constructed in human consciousness and the ideas enacted in the form of language (Halliday 1994:107)

On the other hand, the use of relational process was also noticeable in the clauses in $1 b, 2 c$, 5a, $6 \mathrm{a}$, and $8 \mathrm{a}$ with $15 \%$.

falling waters

$1 \mathrm{~b} \quad$ - $\quad$ Served as the edge of the head high threshold

2c - $\quad$ That carried him across to the narrow door

5a $\quad$ - I'm sorry this dad to be done

$6 \mathrm{a} \quad$ - I am really sorry

8a - $\quad$ The sound of the gangsas beat through the walls of the dark house like muffled roars of

The relational process, a process of being, serves to establish a relation between two separate entities. As the term "relational" suggests, something is being said to "be" something else in relational clauses. There are two types of relational processes: the attributive relational process with the Carrier and the Attribute as the participants, and the identifying relational process with the Identified and the Identifier as the participants.

Relational processes are concerned with the process of being in the world of abstract relations. Normally, an abstract relationship that exists between two participants associated with the process is considered, but unlike the case of material process, a participant does not affect the other participant in a physical sense.

Relational verbs/clauses serve to describe attributes of a thing (relational attributive processes) and identify another thing (relational identifying processes). They construe change as occurring without an input of energy (Matthiessen, 2010).

Lastly, the process type which was once used is the existential process which only obtained $3 \%$ and it is observed in the tenth clause specifically in 10a.

10a - $\quad$ There was a sudden rush of fire in her

The existential process represents existence or happening through a process and a participant that is being said to exist, the Existent. Generally speaking, the existential process is realized by the construction in English which has no representational function and there are no human participants in existential processes.

Table 2: Total Counts of Process

\begin{tabular}{lcc}
\hline \multicolumn{1}{c}{ Process Type } & $\boldsymbol{f}$ & $\%$ \\
\hline Material & 9 & $27 \%$ \\
Mental & 8 & $25 \%$ \\
Behavioral & 9 & $27 \%$ \\
Verbal & 1 & $3 \%$ \\
Relational & 5 & $15 \%$ \\
Existential & 1 & $3 \%$ \\
\hline
\end{tabular}

Indeed, transitivity analysis helps in interpreting and analyzing the character construction in the story for it provides meaningful meanings of the text. Further, the concept of transitivity in Halliday's theory is grammatical system which is a powerful tool for analyzing the meanings 
expressed in clauses. In this research, all the clauses were taken from the short story entitled "The Wedding Dance". As one of literary works, this text conveys messages and meaning to the readers. The transitivity of a text is simply the most important of a number of types of experiential meaning that are found in the clause. The readers can also understand exactly all the processes in a language.

\section{CONCLUSION}

This study aimed to identify the different process types evident in the story "The Mats" and how transitivity analysis helped in interpreting the character construction in the story.

The transitivity system specifies the different types of process that are recognized in the language, and the structures by which they are expressed. The most frequently used processes are Material, Mental and Behavioral processes. The findings of this study revealed the transitivity analysis of the story "The Wedding Dance" represent outer manifestations of inner workings, the acting out of processes of consciousness and physiological states through the use of behavioral process.

It also shows how the actions in the story is being performed and delivered through the medium of material processes. It offers an array of wider understanding of the ideas in the story.

Moreover, the story is embedded with mental process which is concerned with the experience of the world and its consciousness. The story becomes more functional with the presence of relational processes where it provides an idea in the world of abstract relations portrayed by the characters in the story.

There is also a less appearance of verbal and existential processes for the reason that the story's characters seldom express their relationship between ideas constructed in human consciousness. And on the part of existential process, there is a representation of existence with the aid of the process and participant but it is rarely evident.

Furthermore, material and behavioural processes are the two dominating process types present in the portion of the short story where physical experiences of the characters were highlighted including the emphasis of the characters' physiological and psychological behaviour.

Based on the findings of the study, transitivity process types vary in different yet meaningful ways. However, in interpreting and analyzing each process type, consideration of underlying meaning of each clause should be thoroughly examined to avoid some ambiguities for mental and material process types are somehow closely interrelated to each other.

Thus, examining the transitivity process in the text is indeed a delicate task for process types should be identified clearly in the light of semantic properties to explain how the field of the situation is being constructed, and have clear idea how transitivity patterns reflect the nature of the text.

\section{REFERENCES}

Bloor, T., \& Bloor, M. (2004). Functional analysis of English: A Hallidayan approach (2 ${ }^{\text {nd }}$ Ed.). United States of America: Oxford University Press Inc.

Butt, D., (1950) \& National Centre for English Language Teaching and Research (Australia) (2000). Using functional grammar : an explorer's guide (2nd ed). National Centre for English Language Teaching and Research, Macquarie University, Sydney 
Downing, A. \& Locke, P. (2006). English grammar. A University course, $2^{\text {nd }}$ edn. London, New York: Routledge

Gerot, L. \& Wignell, P. (1995). Making Sense of Functional Grammar: An Introductory Workbook. Cammeray, NSW: Antipodean Educational Enterprises.

Halliday, M.A.K. (1967). Notes on transitivity and theme in English, Part 1. Journal of Linguistics, 3(1), 37-81.

Halliday, M. A. K. (1971). Linguistic function and literary style: An inquiry into the language of William Golding's the inheritors. In S. Chatman (Ed.), Literary style: A symposium (pp. 330-368). London: Oxford University Press.

Halliday, M. A. K. (1976). A brief sketch of systemic grammar. In G. Kress (Ed.), System and function in language London: Oxford University Press.

Halliday, M.A.K. 1981. Explorations in The Function of Language. London: Edward Arnold.

Halliday, M.A.K. 1985a. An introduction to Functional Linguistics. London: Edward Arnold.

Halliday, M. A. K. (1994) . An Introduction to Functional Grammar. Second Edition. London : Edward Arnold

Halliday, M.A.K. (2004, 2008). An introduction to functional grammar (3rd ed.). London: Edward Arnold/ Beijing: Foreign Language Teaching and Research Press

Hayes, A. (2019). Simple Random Sample. Retrieved on April 30, 2019 https://www.investopedia.com/terms/s/simplerandom-sample.asp

How the study of stylistics can help improve one's English Language. (2016, Aug 17). Retrieved from https://studymoose.com/how-the-study-of-stylistics-can-help-improve-ones-english-language-essay

Matthiessen, C. (2010). Introduction to functional grammar. Retrieved on January 2, 2018 at http://www.alvinleong.info/sfg/sfgtrans.html

Nordquist, R. (2019) Stylistics and Elements of Style in Literature. Retrieved from https://www.thoughtco.com/stylistics- language-studies-1692000

Pilar, S. (2012). A stylistic analysis of a philippine essay, "the will of the river". Retrieved on January 2, 2018 at http://paclic31.national-u.edu.ph/wp-content/uploads/2017/11/PACLIC_31_paper_52.pdf

Saragih, A. 2010. Introducing Systemic Functional Grammar of English. Medan: FBS UNIMED (unpublished)

Simpson, P., Stylistics (London: Routledge 2004. pp. vi, 247.)

Short, S (1996). English Standard Version (ESV)

Retrieved on December 3, 2017 https://www.coursehero.com/file/20390588/1-Stylistics

Thompson, G. (2000). Introducing functional grammar. London: Arnold/Beijing: Foreign Language Teaching and Research Press.

Trotsky, L. (2017). Literature and Revolution. New York: Russell and Russell, . Retrieved on December 3, 2017 https://www. biblegat eway.com/passage/?search=Psa $1 \mathrm{~m}+4 \&$ version=KJV

Wales, T. (1989). Background to Stylistics and Style. Stylistics is the scientific study of style. .

Retrieved on December 3, 2017 from http://slideplayer.com/slide/4864832/ 